\title{
Congenital Adrenal Hyperplasia
}

National Cancer Institute

\section{Source}

National Cancer Institute. Congenital Adrenal Hyperplasia. NCI Thesaurus. Code C34360.

A genetic disorder characterized by defects in the synthesis of cortisol and/or aldosterone, resulting in hyperplasia of the adrenal cortical cells. 